\title{
The Forest Thrush Turdus lherminieri prefers mature mesic forest with dense canopy
}

\author{
DEVATHI PARASHURAM, STEFFEN OPPEL, CALVIN FENTON, \\ GLENFORD JAMES, JAMES DALEY, GERARD GRAY, NIGEL J. COLLAR and \\ PAUL M. DOLMAN
}

\section{Summary}

Habitat loss, the primary driver for loss of biodiversity worldwide, is of special concern for species that have a small area of occurrence, such as those restricted to islands. The Forest Thrush Turdus lherminieri is a 'Vulnerable' (VU) species endemic to four islands in the Caribbean, and its population has declined dramatically over the past 15 years. Because this decline is poorly understood, we studied its habitat associations on Montserrat. We conducted three repeat point count surveys and measured forest structure and habitat at each of 88 randomly placed locations in the largest forest area remaining on the island. We related Forest Thrush abundance to habitat using binomial mixture models that account for imperfect detection. Detection probability was a function of survey time, survey date, location of the survey point, and wind. Local habitat structure had the greatest influence on Forest Thrush abundance, with birds being more abundant at midelevations under closed canopies. We conclude that the Forest Thrush prefers mature mesic and wet forests on Montserrat. Assuming similar habitat selection in the rest of its range, the species's long-term future depends on good protection of these natural forests on all four islands where it occurs.

\section{Introduction}

Habitat loss is the primary driver for the loss of biodiversity worldwide (Gaston et al. 2003, Pimm et al. 2006, Brook et al. 2008), and is of special concern for species that have small ranges and therefore small populations, such as those restricted to islands (BirdLife International 2000). More than $90 \%$ of bird species extinctions since 1800 have occurred on islands (Johnson and Stattersfield 1990, Banko et al. 2013). Moreover, islands account for $48 \%$ of all Endemic Bird Areas, with more than 600 globally threatened bird species being confined to them (Stattersfield et al. 1998, Ricketts et al. 2005, Dallimer and King 2007). An understanding of the habitat requirements of threatened island-endemic species is therefore crucial to our ability to provide effective management for their long-term conservation.

The Caribbean islands harbour a rich biodiversity and were identified as one of 25 globally important biodiversity hotspots (Myers et al. 2000). Habitat conversion and invasive species threaten native taxa, many of them endemic to these islands, yet little is known about their habitat requirements. The Forest Thrush Turdus lherminieri is restricted to forests on four islands in the Lesser Antilles: Montserrat, Guadeloupe, Dominica and St Lucia (Collar 2005, Eraud et al. 2012), with each island assumed to hold distinct subspecies, T. l. montserrati, T. l. Iherminieri, T. l. dominiciensis and T. l. sanctaeluciae, respectively (Clement and Hathway 2000, Zuccon 2011). The subspecies on St. Lucia may have recently become extinct (last sighting 2007; BirdLife International 2013). Owing to a dramatic overall decline in its population over the last 
15 years, the species is listed as globally 'Vulnerable' (BirdLife International 2013), but the causes of its precarious status on each island are largely a matter of speculation.

Generally, however, the Forest Thrush is believed to be threatened by habitat loss, nest predators and hunting on Guadeloupe (Eraud et al. 2012, BirdLife International 2013). On Guadeloupe the species occurs in areas of continuous rainforest from 110 to $1,400 \mathrm{~m}$ above sea level and wet coastal forests (Eraud et al. 2012, Arnoux et al. 2013). While previous studies have mainly investigated morphological and genetic differentiation (Arnoux et al. 2013, 2014), no study has quantified the habitat preferences of the Forest Thrush. A better understanding of the species's habitat requirements is needed to assess the extent of habitat loss and guide conservation management.

Animals of dense tropical forests are generally difficult to detect. Many studies of habitat associations in birds ignore the fact that some individuals may have been missed during surveys (Kéry et al. 2005, 2009, Kéry 2008). Imperfect detection may affect abundance estimates and habitat inferences if aspects of habitat structure with potential to affect species presence or abundance also affect the ability of an observer to detect the species (Kéry 2008). Two common approaches to account for imperfect detection are distance sampling and repeat surveys using multiple visits or observers (Nichols et al. 2009). Of these, distance sampling is problematic in tropical forests where dense vegetation precludes accurate determination of radial distances, leading to inaccurate density estimations (Alldredge et al. 2007, Simons et al. 2007, Oppel et al. 2014a). However, repeat surveys combined with binomial mixture models allow the estimation of detection probability and provide an excellent basis for analysing habitat preferences (Royle 2004, Kéry et al. 2005, Kéry 2008).

Here we use binomial mixture models to elucidate the habitat associations of the Forest Thrush while accounting for the imperfect detection process in a dense tropical forest. We conducted this study on Montserrat, which holds a significant proportion of the Forest Thrush world population. We use the information about habitat preferences of the Forest Thrush to make recommendations for the conservation of the species and to inform future land management on Montserrat.

\section{Methods}

\section{Study area}

Montserrat $\left(16^{\circ} 45^{\prime} \mathrm{N}, 62^{\circ} 12^{\prime} \mathrm{W}\right)$ is an island of $104 \mathrm{~km}^{2}$, located at the northern end of the Lesser Antilles in the Greater Caribbean Basin. It experiences a moist tropical climate, with an annual rainfall of $1,000-2,500 \mathrm{~mm}$ per year (Hilton et al. 2003). There are three main hill ranges: Silver Hills, Soufrière Hills and Centre Hills, the latter two rising to 700-90o m asl (Young 2008). A range of habitats occur on the island, including dry, mesic and wet forests, and elfin woodland on exposed ridges at high elevations. Following volcanic activity in the Soufrière Hills that started in 1995 , almost $60 \%$ of the island's forest habitat was lost, and now the largest remnant exists in the Centre Hills, with an area of $11 \mathrm{~km}^{2}$ (Young 2008).

\section{Bird monitoring}

Bird surveys were carried out during the breeding season of the Forest Thrush in April 2013. We conducted 10-minute point counts between o6hoo and I4hoo Atlantic Standard Time (AST), during which all visual and acoustic detections of the Forest Thrush were recorded. Point counts were carried out three times per point over a three-week period at 88 survey points located randomly within the Centre Hills forest, with a minimum of $200 \mathrm{~m}$ between points (for details see Dalsgaard et al. 2007, Oppel et al. 2014a).

\section{Habitat data}

Based on previous work on related species (Jones et al. 1995, Dallimer and King 2007, RangelSalazar et al. 2008), we recorded geographical and habitat variables that might influence Forest 
Thrush abundance at each point (Table 1). Land cover type at the survey point, distance to permanent water sources and distance to forest edge or clearing (roughly $10 \mathrm{~m}^{2}$ or larger) were obtained from high-resolution aerial images available on a GIS web-platform (http://landinfo.gov.ms/, accessed 14 April 2013) (Table 1).

\section{Data analysis}

We aimed to relate the abundance of the Forest Thrush to various habitat variables. While habitat or landscape variables usually influence species occurrence and abundance, some habitat features and other variables (e.g. wind, rain, sampling time) may affect an observer's ability to detect the species (Royle and Dorazio 2008, Nichols et al. 2009). To account for imperfect detection in our data we used binomial mixture models (BMM), which are a class of hierarchical models that require spatial as well as temporal replication of counts (Royle and Nichols 2003, Kéry et al. 2005, Royle et al. 2005); they have already been used with forest bird monitoring data on Montserrat (Oppel et al. 2014a). A critical assumption for BMMs is that the population is demographically closed over the period during which the repeat surveys are conducted. To satisfy this assumption, repeat surveys of the same survey points were conducted within 2-3 weeks, during which demographic closure is highly likely.

BMMs consist of a hierarchy of two Generalised Linear Models (GLMs), the first of which models the observation process to estimate detection probability while the second models true abundance in relation to environmental variables, given that not all birds are detected (Kéry and Schaub 2012). We modelled the abundance component as a random Poisson process to estimate the size of the local 'superpopulation' of birds whose home range overlaps the radius around a

Table 1. Definitions of survey-specific detection covariates, geographical and habitat variables recorded at 88 survey points across the Centre Hills on Montserrat in 2013.

\begin{tabular}{|c|c|c|}
\hline Variable & Metric & Definition \\
\hline \multicolumn{3}{|c|}{ Survey-specific detection/observation covariates } \\
\hline Rain & categorical & $\mathrm{o}=$ no rain, $1=$ rain during the count \\
\hline Wind & categorical & $\begin{array}{l}\text { Strength of wind during count in two categories: calm/light or } \\
\text { moderate/strong }\end{array}$ \\
\hline Survey date & date & Date when survey was conducted \\
\hline Survey time & time & Time at which survey was conducted \\
\hline \multicolumn{3}{|l|}{ Geographical variables } \\
\hline Elevation & $\mathrm{m}$ & Metres above sea-level recorded by GPS (Garmin GPSmap 6os) \\
\hline Location & categorical & Two categories: valley/midslope or ridge \\
\hline Land cover type & categorical & $\begin{array}{l}\text { Type of vegetation cover at the survey point in three categories- } \\
\text { dry forest, mesic forest, and wet forest. Elfin woodland was } \\
\text { recorded at only three points and was classed as 'wet forest'. }\end{array}$ \\
\hline $\begin{array}{l}\text { Distance to forest } \\
\text { edge/clearing }\end{array}$ & $\mathrm{m}$ & Distance of survey point from forest edge or manmade clearing \\
\hline $\begin{array}{l}\text { Distance to permanent } \\
\text { water source }\end{array}$ & $\mathrm{m}$ & Distance of survey point from permanent ghaut or river \\
\hline \multicolumn{3}{|l|}{ Habitat variables } \\
\hline Canopy cover & $\%$ & Cover of tree canopy estimated with a spherical densiometer \\
\hline Tree density & trees $/ \mathrm{m}^{2}$ & $\begin{array}{l}\text { Calculated using Point-Centered Quarter method (Cottam and } \\
\text { Curtis 1956). We defined a tree as a plant with woody trunk at } \\
\text { breast height and }>5 \mathrm{~m} \text { in height. }\end{array}$ \\
\hline Tree height & $\mathrm{m}$ & $\begin{array}{l}\text { Mean of heights of tallest tree in each of four } 90^{\circ} \text { quadrants } \\
\text { around the survey point, measured with a range finder, within } \\
\text { a maximum radius of } 30 \mathrm{~m}\end{array}$ \\
\hline
\end{tabular}


sampling station. We used a Poisson rather than a negative binomial distribution, as the negative binomial distribution generally yields larger and less precise estimates for count data of common species (Kéry et al. 2005, Joseph et al. 2009, Hunt et al. 2012). The observation model component was conditional on the number of birds estimated at each sampling station, and calculated the probability of detection based on repeated counts at a given site using binomial trials for each bird.

We constructed multiple biologically plausible candidate models in three hierarchical steps. First, we tested models describing the detection process, while keeping abundance constant. We considered that wind, survey time, survey date, rain and location of the survey point might affect detection probability, and explored all possible combinations of these variables, including quadratic effects of survey date to account for non-linear change in detection probability (Schmidt et al. 2013). In the second step, we explored all possible combinations of site-specific habitat covariates (elevation, tree height, tree density, canopy cover) as well as a quadratic effect of elevation on Forest Thrush abundance in a suite of models that included all detection covariates from the most parsimonious detection model. For sedentary forest species such as the Forest Thrush local habitat is usually the primary factor affecting abundance, while landscape-scale variables have a weaker secondary effect (Dolman 2012). Hence, in a third step, we added landscape effects (distance to forest edge, distance to permanent water source, land cover type) to the most parsimonious local habitat model, while retaining the detection covariates. Because some landscape variables were strongly correlated with elevation $(r>0.5$; land cover type and distance to forest edge), we omitted combinations of these correlated variables in the third step. Across the three steps, we constructed a total of 841 models to test detection covariates and habitat relationships of the Forest Thrush. We used an information-theoretic approach to select the most parsimonious model from all three steps (Burnham and Anderson 2002) and used the most parsimonious model for inference to avoid overestimation of variable importance based on model weights (Galipaud et al. 2014).

All numeric site and survey-specific covariates were standardised by rescaling so that all predictors had zero mean and unit variance, in order to enhance the convergence of the numerical optimisation algorithm (Kéry et al. 2005). All categorical variables were structured as ordered factors, except for location of point and land cover type, which were structured simply as factors. All models were fitted using the 'pcount' function in the 'unmarked' package (Fiske and Chandler 2011), and models with combinations of terms were tested using the 'dredge' function in the 'MuMIn' package (Barton 2014) in R version 3.1.o (R Development Core Team 2014).

The goodness of fit of the most parsimonious model was assessed with Pearson's $\chi^{2}$ statistic via 200 simulations using parametric bootstrap. If the observed statistic is not too extreme (beyond the 0.05 percentile of the reference distribution), then the model fits (Sillett et al. 2012). In addition, lack of model fit was quantified using the overdispersion parameter $\hat{c}$ as follows:

$$
\hat{c}=X_{O b s}^{2} / \bar{X}_{B}^{2}
$$

where $\bar{X}_{B}^{2}$ is the average of the test statistics obtained from the parametric bootstrap. If the model is an adequate description of the data, then $\hat{c}$ should be approximately 1 (MacKenzie and Bailey 2004).

Although the average home range size of 30 radio-tracked male Forest Thrushes during the breeding season on Guadeloupe was $0.08-0.2 \mathrm{~km}^{2}$ and the maximum distance covered in a day was $<200 \mathrm{~m}$ (Eraud et al. 2012), the distance between points may not have been sufficient to ensure complete spatial independence of point counts, which would affect the inference drawn from models. We therefore examined spatial independence of samples by calculating Moran's I of the most parsimonious model residuals using the function 'moran.test' in the R-package 'spdep'.

\section{Results}

We counted 480 Forest Thrushes at the 88 survey points during the three repeat surveys, with o- 6 birds encountered during each point count and most detections $(>90 \%)$ being aural. The best detection model included wind, time, location of point and survey date, and indicated that detection probability was generally low (mean $\pm \mathrm{SD}=0.16 \pm 0.06$, range $0.05-0.30$ ) and decreased 
later in the morning, with stronger wind, and when point count stations were located on ridges, but increased in the middle of the month-long field survey (Figure 1, Table 2). Including these detection covariates, there was overwhelming support for elevation and canopy cover as determinants of Forest Thrush abundance (Tables 2,3). Predicted Forest Thrush abundance ranged from $1-15$ birds per point (mean $\pm S D=11 \pm 3$ birds), increased with canopy cover, and was highest at intermediate elevations (Figure 1 ). The bootstrap $P$ value for the most parsimonious model based on Pearson's $\chi^{2}$ statistic was 0.71 , suggesting that it provided an adequate fit to the data. The overdispersion parameter $\hat{c}=0.94$ indicated that there was no evidence for a lack of fit of this model. There was no spatial autocorrelation of the model residuals (Moran's $I=-0.011, P=0.49$ ).

There were ten models across the three steps of the model selection process, which were within three AICc units of the most parsimonious model (Table 2). These models provided some evidence that tree height and distance to a permanent water source could affect the abundance of Forest Thrush. While tree height had a positive effect on abundance (abundance parameter estimate $0.096 \pm 0.066 \mathrm{SE}$ ), Forest Thrushes appeared to be marginally less abundant in areas farther from a water source (-0.0524 $\pm 0.057 \mathrm{SE})$, but the effect size of these two variables was lower than for the variables in the most parsimonious model (Table 3 ).

\section{Discussion}

Canopy cover and elevation influence Forest Thrush abundance on Montserrat, with birds being more abundant at mid-elevations, dominated by closed canopies. Since land cover type and habitat

a)

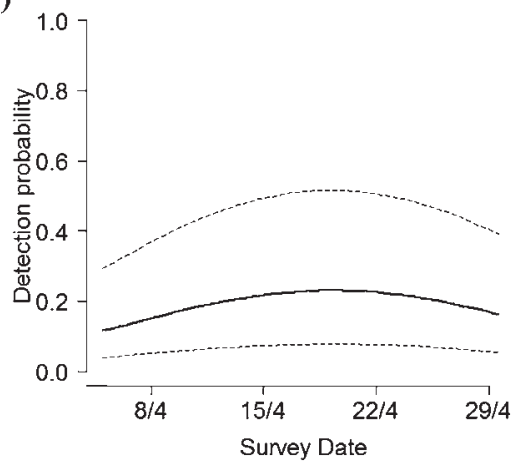

c)

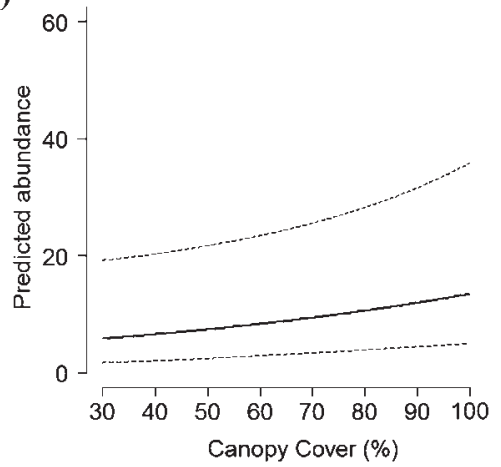

b)

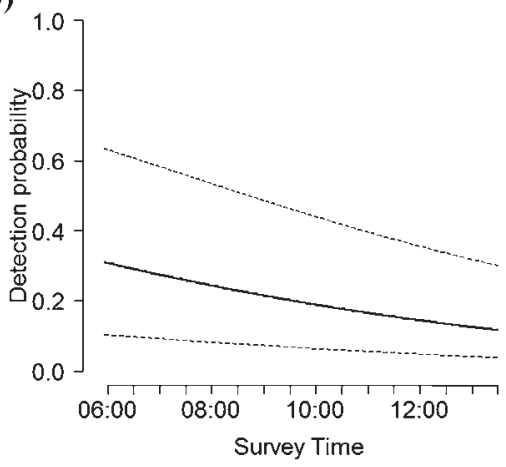

d)

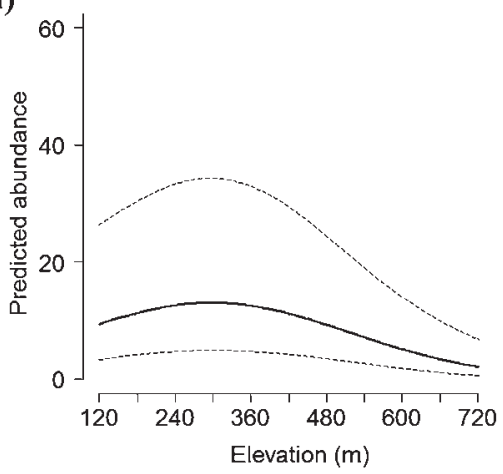

Figure 1 . Factors influencing detection probability $(a-b)$, and habitat variables influencing Forest Thrush abundance (c-d) in the Centre Hills of Montserrat, 2013, from the most parsimonious binomial mixture model. Dotted lines represent $95 \%$ confidence intervals. 
Table 2. Top ten candidate binomial mixture models across all three steps of the model selection process, describing the detection and ecological processes involved in explaining abundance of Forest Thrush at 88 survey points in the Centre Hills of Montserrat in 2013. Covariates influencing abundance $(\lambda)$ and detection probability $(p)$ in each model are listed. Squared terms indicate quadratic effects.

\begin{tabular}{|c|c|c|c|c|c|}
\hline Model no. & $\lambda$ & $P$ & $\begin{array}{l}\text { No. of } \\
\text { parameters }\end{array}$ & AICc & $\triangle \mathrm{AICc}$ \\
\hline 1 & elev + elev $^{2}+$ canopy & $\begin{array}{l}\text { date }+ \text { date }^{2}+\text { loc }+ \text { time }+ \\
\text { wind }\end{array}$ & 10 & 808.54 & 0.00 \\
\hline 2 & elev + elev $^{2}+$ canopy + treeheight & $\begin{array}{l}\text { date }+ \text { date }^{2}+\text { loc }+ \text { time }+ \\
\text { wind }\end{array}$ & 11 & 809.08 & 0.54 \\
\hline 3 & $e^{e l e v}+$ canopy & $\begin{array}{l}\text { date }+ \text { date }^{2}+\text { loc }+ \text { time }+ \\
\text { wind }\end{array}$ & 9 & $809 \cdot 73$ & 1.19 \\
\hline 4 & $\mathrm{elev}^{2}$ & $\begin{array}{l}\text { date }+ \text { date }^{2}+\text { loc }+ \text { time }+ \\
\text { wind }\end{array}$ & 8 & 809.93 & 1.39 \\
\hline 5 & elev + elev $^{2}+$ canopy + dist_to_water & $\begin{array}{l}\text { date }+ \text { date }^{2}+\text { loc }+ \text { time }+ \\
\quad \text { wind }\end{array}$ & 11 & 810.29 & 1.75 \\
\hline 6 & elev + elev² & $\begin{array}{l}\text { date }+ \text { date } e^{2}+\text { loc }+ \text { time }+ \\
\text { wind }\end{array}$ & 9 & 810.43 & 1.89 \\
\hline 7 & $\mathrm{elev}^{2}+$ canopy + treeheight & $\begin{array}{l}\text { date }+ \text { date }{ }^{2}+\text { loc }+ \text { time }+ \\
\text { wind }\end{array}$ & 10 & 810.91 & 2.37 \\
\hline 8 & elev + elev $^{2}+$ canopy + treedens & $\begin{array}{l}\text { date }+ \text { date }^{2}+\text { loc }+ \text { time }+ \\
\quad \text { wind }\end{array}$ & 11 & 811.12 & 2.58 \\
\hline 9 & elev $^{2}+$ treeheight & $\begin{array}{l}\text { date }+ \text { date }^{2}+\text { loc }+ \text { time }+ \\
\text { wind }\end{array}$ & 9 & 811.40 & 2.86 \\
\hline 10 & elev + elev² + treeheight & $\begin{array}{l}\text { date }+ \text { date }^{2}+\text { loc }+ \text { time }+ \\
\quad \text { wind }\end{array}$ & 10 & 811.49 & 2.95 \\
\hline
\end{tabular}

AICc $=$ Corrected Akaike information criterion.

canopy $=\%$ canopy cover, date $=$ survey date, dist_to_water $=$ distance to permanent water source, elev = elevation, loc = location of survey point, time = survey time, treedens = tree density, treeheight $=$ tree height, wind $=$ strength of wind (see Table 1 for details of measurements).

type change along an elevational gradient, elevation was used as a proxy to make inferences about the type of forest that the species prefers. On Montserrat, the elevational habitat gradient is probably driven by moisture, as higher elevations receive more rainfall (Barclay et al. 2006). Forest

Table 3. Parameter estimates from the most parsimonious binomial mixture model explaining abundance of forest thrush at 88 survey points in the Centre Hills of Montserrat in 2013. All variables were standardised (to unit mean and variance) for comparability of parameters.

\begin{tabular}{lcc}
\hline Submodel and coefficient & Estimate & Standard error \\
\hline Abundance $(\boldsymbol{\lambda}):$ & & \\
\hline Intercept & 2.53 & 0.50 \\
Elevation & -0.16 & 0.08 \\
Elevation ${ }^{2}$ & -0.23 & 0.06 \\
Canopy cover & 0.13 & 0.06 \\
\hline Detection $(p):$ & & \\
\hline Intercept & -1.41 & 0.63 \\
Strong wind & -0.28 & 0.09 \\
Location on ridge & -0.54 & 0.24 \\
Survey time & -0.27 & 0.07 \\
Survey date & 0.10 & 0.06 \\
Survey date & & 0.06 \\
\hline
\end{tabular}


Thrush abundance was greatest at elevations of $200-400 \mathrm{~m}$, which are dominated by mature secondary mesic forests, and declined slightly with further increase in elevation. There was also some evidence that Forest Thrushes were more abundant in areas with taller trees and closer to permanent water sources, but these effects were less pronounced than canopy cover and elevation. Overall, our findings provide quantitative support for qualitative descriptions of Forest Thrush distribution and habitat elsewhere (Eraud et al. 2012).

Many forest- and woodland-dwelling thrush species are strongly adapted to forage terrestrially in leaf-litter, but generally breed and sometimes feed in the canopy (Collar 2005). Because leaflitter is thickest and supports a greater abundance of animal life in relatively level ground under a dense canopy, where low light conditions discourage obstructive undergrowth (Canham et al. 1990, Bartels and Chen 2013), the greater abundance of Forest Thrushes in such habitat probably reflects better foraging habitat. Dense canopy cover and reduced lighting may also increase nesting success by reducing visual detection by nest predators (in this case, Pearly-eyed Thrashers Margarops fuscatus), as has been found in Ruddy-capped Nightingale-thrushes Catharus frantzii in Mexico, which enjoy higher nesting success under closed canopies (Rangel-Salazar et al. 2008).

Unsurprisingly, detection probability in our study decreased with increasing strength of wind, and use of ridges as survey points: birds are less audible in windy conditions (Simons et al. 2007), and ridges hold inappropriate foraging substrates while their steep slopes reduce audibility. If not accounted for, this artifact of the observation process might have been mistaken for low Forest Thrush abundance on ridges. It therefore highlights the value of using binomial mixture models to study habitat preferences (Kéry 2008). We also found that detection probability decreased with time of day, which is a well-known phenomenon among songbirds, which often change their vocal activity through the day (Bibby et al. 2000, Schmidt et al. 2013). However, as singing intensity increased in the second half of April we observed an intermittent increase in detection probability during the breeding season. Because the monitoring programme on Montserrat was originally designed for a different species with a slightly earlier breeding period, the first round of point count surveys recorded very few singing Forest Thrushes and it is therefore not surprising that detection probability increased over time.

The estimated abundance of birds per survey point in our study was quite large ( $>15$ birds/point, Fig. I), a fact that has been recognised in other applications of binomial mixture models (Hunt et al. 2012). Binomial mixture models estimate the size of a 'super-population', which is the number of birds that use the habitat around a counting station (Nichols et al. 2009, Kéry and Schaub 2012). Thus, overlapping home ranges of several pairs, which has been recorded for radio-tracked individuals on Guadeloupe (Eraud et al. 2012), will lead to several pairs using the same forest area and would thus explain the high estimated abundance per point. Although we are not able to convert our estimates of abundance into density and thus total population size of Forest Thrushes on Montserrat, we are confident that these estimates are reliable to infer habitat associations and to model population changes over time (Parashuram 2013).

Our study has important implications for the conservation of the Forest Thrush. The preferred forest habitat for the species includes tall mesic forests with closed canopies, which have matured after forest clearance for agriculture in previous centuries and more recent natural disasters (Lugo et al. 1981, Arendt 1990, Dalsgaard et al. 2007). Both natural and semi-natural forests are still threatened by human development on all islands in the range of the Forest Thrush (BirdLife International 2014). In addition, intense grazing pressure from feral livestock may alter the forest structure and inhibit regeneration, with potentially negative consequences for the Forest Thrush (Peh et al. 2014). For the long-term survival of this and other island species, it is critical to retain as much forest cover as possible to allow for population shifts in response to stochastic environmental events such as hurricanes and volcanic eruptions, which are frequent in the Caribbean (Tanner et al. 1991) and have led to major distributional shifts of birds, especially on Montserrat, in the last two decades (Arendt et al. 1999, Oppel et al. 2014b). While our study has clarified the habitat associations of the Forest Thrush on Montserrat, urgent work is now needed to establish forest management programmes that protect significant areas of mature forest from damage from overgrazing and losses to human development. 


\section{Acknowledgements}

We thank L. Martin, J. Boatswain, A. Homer and L. Bambini for assistance with fieldwork and data entry. L. Rogers of the Montserrat Physical Planning Unit kindly granted access to the highresolution aerial images and GIS resources of the island. The Montserrat Department of Environment provided invaluable logistical support.

\section{References}

Alldredge, M. W., Simons, T. R. and Pollock, K. H. (2007) A field evaluation of distance measurement error in auditory avian point count surveys. J. Wildl. Manage. 71 : 2759-2766.

Arendt, W. J., Gibbons, D. W. and Gray, G. A. L. (1999) Status of the volcanically threatened Montserrat Oriole Icterus oberi and other forest birds in Montserrat, West Indies. Bird Conserv. Internatn. 9: 351-372.

Arendt, W. J. (1990) Impact of Hurricane Hugo on the Montserrat Oriole, other forest birds, and their habitat. Río Pedras, Puerto Rico: US Department of Agriculture, Forest Service, Institute of Tropical Forestry.

Arnoux, E., Eraud, C., Thomas, A., Cavallo, F., Garnier, S. and Faivre, B. (2013) Phenotypic variation of Forest Thrushes Turdus lherminieri in Guadeloupe: evidence for geographic differentiation at fine spatial scale. J. Ornithol. 154: 977-985.

Arnoux, E., Eraud, C., Navarro, N., Tougard, C., Thomas, A., Cavallo, F., Vetter, N., Faivre, B. and Garnier, S. (2014) Morphology and genetics reveal an intriguing pattern of differentiation at a very small geographic scale in a bird species, the forest thrush Turdus lherminieri. Heredity: 1-12.

Banko, P. C., Camp, R. J., Farmer, C., Brinck, K. W., Leonard, D. L. and Stephens, R. M. (2013) Response of palila and other subalpine Hawaiian forest bird species to prolonged drought and habitat degradation by feral ungulates. Biol. Conserv. 157: 70-77.

Barclay, J., Johnstone, J. E. and Matthews, A. J. (2006) Meteorological monitoring of an active volcano: implications for eruption prediction. J. Volcanol. Geotherm. Res. 150: 339-358.

Bartels, S. F. and Chen, H. Y. H. (2013) Interactions between overstorey and understorey vegetation along an overstorey compositional gradient. J. Veg. Sci. 24: 543-552.
Barton, K. (2014) MuMIn: Multi-model inference. R package version 1.10.0. Available at: http://CRAN.R-project.org/package=MuMIn.

Bibby, C. J., Burgess, N. D., Hill, D. A. and Mustoe, S. H. (2000) Bird census techniques. $2^{\text {nd }}$ ed. London, UK: Academic Press.

BirdLife International (2000) Threatened birds of the world. Barcelona and Cambridge: Lynx Edicions and BirdLife International.

BirdLife International (2013) Species factsheet: Turdus lherminieri. vol. 2013. http://www. birdlife.org.

BirdLife International (2014) Endemic Bird Area factsheet: Lesser Antilles. http://www. birdlife.org

Brook, B. W., Sodhi, N. S. and Bradshaw, C. J. (2008) Synergies among extinction drivers under global change. Trends Ecol. Evol. 23: 453-46o.

Burnham, K. P. and Anderson, D. R. (2002) Model selection and multimodel inference: A practical information-theoretic approach. New York, USA: Springer.

Canham, C. D., Denslow, J. S., Platt, W. J., Runkle, J. R., Spies, T. A. and White, P. S. (1990) Light regimes beneath closed canopies and tree-fall gaps in temperate and tropical forests. Can. J. For. Res. 20: 620-631.

Clement, P. and Hathway, R. (2000) Thrushes. London, UK: Christopher Helm.

Collar, N. J. (2005) Family Turdidae (thrushes and chats). Pp. 5I4-807 in J. Del Hoyo, A. Elliott and D. Christie, eds. Handbook of the birds of the world. Volume 10 Cuckoo-shrikes to thrushes. Barcelona: Lynx Edicions.

Cottam, G. and Curtis, J. T. (1956) The use of distance measures in phytosociological sampling. Ecology 37: 451-460.

Dallimer, M. and King, T. (2007) Habitat preferences of the forest birds on the island of Príncipe, Gulf of Guinea. Afr. J. Ecol. 46: 258-266. 
Dalsgaard, B., Hilton, G. M., Gray, G. A. L., Aymer, L., Boatswain, J., Daley, J., Fenton, C., Martin, J., Martin, L., Murrain, P., Arendt, W. J., Gibbons, D. W. and Olesen, J. M. (2007) Impacts of a volcanic eruption on the forest bird community of Montserrat, Lesser Antilles. Ibis 149: 298-312.

Dolman, P. M. (2012) Mechanisms and processes underlying landscape structure effects on bird populations. Cambridge, UK: Cambridge University Press.

Eraud, C., Arnoux, E., Levesque, A., Van Laere, G. and Magnin, H. (2012) Biologie des populations et statut de conservation des oiseaux endémiques des Antilles en Guadeloupe. Rapport d'étude ONCFS-Parc National Guadeloupe.

Fiske, I. J. and Chandler, R. B. (2011) unmarked: An R package for fitting hierarchical models of wildlife occurrence and abundance. J. Stat. Softw. 43:1-23.

Galipaud, M., Gillingham, M. A. F., David, M. and Dechaume-Moncharmont, F. X. (2014) Ecologists overestimate the importance of predictor variables in model averaging: a plea for cautious interpretations. Methods Ecol. Evol. 5: 983-991.

Gaston, K. J., Blackburn, T. M. and Goldewijk, K. K. (2003) Habitat conversion and global avian biodiversity loss. Proc. Roy. Soc. Lond. Ser. B: Biol. Sci. 270: 1293-1300.

Hilton, G. M., Atkinson, P. W., Gray, G. A. L., Arendt, W. J. and Gibbons, D. W. (2003) Rapid decline of the volcanically threatened Montserrat oriole. Biol. Conserv. 111: 79-89.

Hunt, J. W., Weckerly, F. W. and Ott, J. R. (2012) Reliability of occupancy and binomial mixture models for estimating abundance of Golden-cheeked Warblers (Setophaga chrysoparia). Auk 129: 105-114.

Johnson, T. H. and Stattersfield, A. J. (1990) A global review of island endemic birds. Ibis 132: 167-180.

Jones, M. J., Linsley, M. D. and Marsden, S. J. (1995) Population sizes, status and habitat associations of the restricted-range bird species of Sumba, Indonesia. Bird Conserv. Internatn. 5: 21-52.

Joseph, L. N., Elkin, C., Martin, T. G. and Possingham, H. P. (2009) Modeling abundance using $\mathrm{N}$-mixture models: the importance of considering ecological mechanisms. Ecol. Appl. 19: 631-642.

Kéry, M. (2008) Estimating abundance from bird counts: Binomial mixture models uncover complex covariate relationships. Auk 125: 336-345.

Kéry, M. and Schaub, M. (2012) Bayesian population analysis using WinBUGS. Oxford, UK: Academic Press.

Kéry, M., Dorazio, R. M., Soldaat, L., van Strien, A., Zuiderwijk, A. and Royle, J. A. (2009) Trend estimation in populations with imperfect detection. J. Appl. Ecol. 46: 1163-1172.

Kéry, M., Royle, J. A. and Schmid, H. (2005) Modeling avian abundance from replicated counts using binomial mixture models. Ecol. Applic. 15: 1450-1461.

Lugo, A. E., Schmidt, R. and Brown, S. (1981) Tropical forests in the Caribbean. Ambio: 318-324.

MacKenzie, D. I. and Bailey, L. L. (2004) Assessing the fit of site-occupancy models. J. Agr. Biol. Envir. St. 9: 300-318.

Myers, N., Mittermeier, R. A., Mittermeier, C. G., da Fonseca, G. A. B. and Kent, J. (2000) Biodiversity hotspots for conservation priorities. Nature 403: 853-858.

Nichols, J. D., Thomas, L. and Conn, P. B. (2009) Inferences about landbird abundance from count data: recent advances and future directions. Pp. 201-235 in D. L. Thomson, E. G. Cooch, G. Evan and M. J. Conroy, eds. Modeling demographic processes in marked populations. New York, USA: Springer. Environmental and Ecological Statistics 3.

Oppel, S., Cassini, A., Fenton, C., Daley, J. and Gray, G. (2014a) Population status and trend of the Critically Endangered Montserrat Oriole. Bird Conserv. Internatn. 24: 252-261.

Oppel, S., Hilton, G. M., Ratcliffe, N., Fenton, C., Daley, J., Gray, G., Vickery, J. A. and Gibbons, D., (2014b). Assessing population viability while accounting for demographic and environmental uncertainty. Ecology 95: 1809-1818.

Parashuram, D. (2013) Population trend and habitat associations of the Forest Thrush (Turdus lherminieri) on Montserrat, West Indies. M.Sc. Thesis, University of East Anglia.

Peh, K., Balmford, A., Birch, J., Brown, C., Butchart, S., Daley, J., Dawson, J., Gray, G., 
Hughes, F., Mendes, S., Millet, J., Stattersfield, A., Thomas, D., Walpole, M. and Bradbury, R. (2014) Potential impact of invasive alien species on ecosystem services provided by a tropical forested ecosystem: a case study from Montserrat. Biol. Invasions: 1-15.

Pimm, S., Raven, P., Peterson, A., Şekercioğlu, Ç. H. and Ehrlich, P. R. (2006) Human impacts on the rates of recent, present, and future bird extinctions. P. Natl. Acad. Sci. USA 103: 10941-10946.

R Development Core Team (2014) R: A language and environment for statistical computing. Available at: http://www.r-project. org/. Vienna, Austria: R Foundation for Statistical Computing.

Rangel-Salazar, J. L., Martin, K., Marshall, P. and Elner, R. W. (2008) Influence of habitat variation, nest-site selection, and parental behavior on breeding success of RuddyCapped Nightingale Thrushes (Catharus frantzii) in Chiapas, Mexico. Auk 125: $358-367$.

Ricketts, T. H., Dinerstein, E., Boucher, T., Brooks, T. M., Butchart, S. H. M., Hoffmann, M., Lamoreux, J. F., Morrison, J., Parr, M., Pilgrim, J. D., Rodrigues, A. S. L., Sechrest, W., Wallace, G. E., Berlin, K., Bielby, J., Burgess, N. D., Church, D. R., Cox, N., Knox, D., Loucks, C., Luck, G. W., Master, L. L., Moore, R., Naidoo, R., Ridgely, R., Schatz, G. E., Shire, G., Strand, H., Wettengel, W. and Wikramanayake, E. (2005) Pinpointing and preventing imminent extinctions. P. Natl. Acad. Sci. USA: 18497-18501.

Royle, J. A. (2004) N-mixture models for estimating population size from spatially replicated counts. Biometrics 60: 108-115.

Royle, J. A. and Dorazio, R. M. (2008) Hierarchical modeling and inference in ecology, $1^{\text {st }}$ ed. New York, USA: Academic Press.
Royle, J. A. and Nichols, J. D. (2003) Estimating abundance from repeated presence-absence data or point counts. Ecology 84: 777-790.

Royle, J. A., Nichols, J. D. and Kéry, M. (2005) Modelling occurrence and abundance of species when detection is imperfect. Oikos I10: 353-359.

Schmidt, J. H., McIntyre, C. L. and MacCluskie, M. C. (2013) Accounting for incomplete detection: What are we estimating and how might it affect long-term passerine monitoring programs? Biol. Conserv. 160: 130-139.

Sillett, T. S., Chandler, R. B., Royle, J. A., Kéry, M. and Morrison, S. A. (2012) Hierarchical distance-sampling models to estimate population size and habitat-specific abundance of an island endemic. Ecol. Applic. 22: 1997-2006.

Simons, T. R., Alldredge, M. W., Pollock, K. H., Wettroth, J. M. and Dufty, A. M, Jr. (2007) Experimental analysis of the auditory detection process on avian point counts. Auk 124: 986-999.

Stattersfield, A. J., Crosby, M. J., Long, A. J. and Wege, D. C. (1998) Endemic bird areas of the world: Priorities for biodiversity conservation. Cambridge, UK: BirdLife International.

Tanner, E. V. J., Kapos, V. and Healey, J. R. (1991) Hurricane effects on forest ecosystems in the Caribbean. Biotropica 23: 513-521.

Young, R. P. (2008) A biodiversity assessment of the Centre Hills, Montserrat. Jersey, Channel Islands, UK: Durrell Wildlife Conservation Trust and Kew Botanical Gardens.

Zuccon, D. (2011) A new name for the Montserrat Forest Thrush. Bull. Brit. Ornithol. Club 131: 199-200.

\section{DEVATHI PARASHURAM*, PAUL M. DOLMAN}

School of Environmental Sciences, University of East Anglia, Norwich Research Park, Norwich, $\mathrm{NR}_{4}{ }_{7 T} \mathrm{TJ}, \mathrm{UK}$.

\section{STEFFEN OPPEL}

RSPB Centre for Conservation Science, Royal Society for the Protection of Birds, The Lodge, Sandy, Bedfordshire, SG19 IQX, UK. 


\section{CALVIN FENTON, GLENFORD JAMES, JAMES DALEY, GERARD GRAY}

Montserrat Department of Environment, PO Box 272, Brades, Montserrat, West Indies.

NIGEL J. COLLAR

BirdLife International, Wellbrook Court, Girton Road, Cambridge, CB3 oNA, UK.

*Author for correspondence; email:devathip@gmail.com

Received II August 2014; revision accepted 21 November 2014; Published online 2 February 2015 